\title{
Higher Education music students' perceptions of the benefits of participative music making
}

\author{
Dimitra Kokotsaki, School of Education, University of Durham
}

\section{Susan Hallam, Institute of Education, University of London}

Contact: Prof. Susan Hallam, Institute of Education, University of London, 20 Bedford Way, London, WC1H OAL

s.hallam@ioe.ac.uk or shallam@globalnet.co.uk

Phone: 02076126371

Dimitra Kokotsaki is jointly appointed by the CEM Centre (Curriculum, Evaluation and Management Centre) and the School of Education at the University of Durham. As a member of the Education Evaluation Group, she is carrying out a variety of evaluations of educational initiatives. She is currently involved in the evaluation of the Creative Partnerships project at Tees Valley, and North and South Tyneside. Her teaching role at the School of Education involves running the PGCE in secondary music education. Her research interests include musical performance anxiety, ensemble playing, social interaction and the psychology of musical performance, and issues relating to the education of trainee teachers and music teachers' job satisfaction and professional well-being. She has published relevant research studies in academic journals. 
Susan Hallam is Professor of Education at the Institute of Education, University of London and currently Head of the Institute's School of Lifelong Education and International Development. She pursued careers as both a professional musician and a music educator before becoming an academic in 1991. Her research interests include disaffection from school, ability grouping and homework and issues relating to learning in music, practising, performing, musical ability, musical understanding and the effects of music on behaviour and studying. She is the author of ten books including Instrumental Teaching: A Practical Guide to Better Teaching and Learning (1998), The Power of Music (2001) and Music Psychology in Education (2005) and over one hundred other scholarly contributions. She is Chair of the Education Section of the British Psychological Society and an Academician of the Learned Societies for the Social Sciences. 


\title{
Higher Education music students' perceptions of the benefits of participative music making
}

\begin{abstract}
This study aimed to assess the perceived impact of music students' active engagement in music making. Seventy-eight music students were asked to report on the impact that their participation in music making had on their lives. The data were analysed using Atlas.ti software. The findings fell within three categories. Music making as a musical act, which allowed participants to deepen their musical knowledge and understanding. Music making as a social act, where students felt that they were active contributors to a group outcome, developed a strong sense of belonging, gained popularity and made friends with 'likeminded' people, enhancing their social skills, and building up a strong sense of self-esteem and satisfaction; and active music making influencing the self in terms of personal skill development facilitating the students' personal identity and encouraging the development of self-achievement, self-confidence and intrinsic motivation.
\end{abstract}




\section{Higher Education music students' perceptions of the benefits of participative music making}

\section{Introduction}

Practical music making has been shown to have benefits beyond the development of a range of musical skills in children and adults. Music lessons designed to develop auditory, visual and motor skills have benefited reading skills (Douglas and Willatts, 1994), children's engagement with the Kodaly method has improved reading and arithmetic (Gardiner et al., 1996) and there is evidence that there are increases in children's Intelligence Quotient when they engage in practical music making (Schellenberg, 2004), although not all of the evidence supports these findings (Hurwitz et al., 1975; Hetland, 2000) and some effects have been found to be transitory (Costa-Giomi, 1999).

Music has also been shown to enhance a range of social and personal skills. Research in Switzerland showed that increasing the amount of classroom music within the curriculum did not have a detrimental effect on language and reading skills despite a reduction in time in these lessons (Spychiger, et al., 1993; Zulauf, 1993) and there was an increase in social cohesion within class, greater self-reliance, better social adjustment and more positive attitudes in the children. These effects were particularly marked in low ability, disaffected pupils (Spychiger, et al., 1993; Hanshumaker, 1980). Active engagement with music can also increase self-esteem in children of low economic status (Costa-Giomi, 1999) and increase social inclusion (Ings et al., 2000). In UK secondary schools pupils' engagement with music has been shown to enhance awareness of others, social skills, well-being, confidence in performance, group work, and self expression. Some students referred to the 
sheer fun and therapeutic nature of music, and those who played instruments mentioned an increase in self-esteem and sense of identity (Harland et al., 2000). Supporting this instrumental teachers believe that the benefits of learning to play an instrument include the development of social skills; gaining a love and enjoyment of music; developing teamwork; developing a sense of achievement, confidence and self-discipline; and developing physical co-ordination (Hallam and Prince, 2000). Other major national reports on the arts have emphasised their importance in developing a range of transferable skills including those related to creativity and critical thinking (NACCCE, 1999).

Similarly, studies of adult participation in music have demonstrated a range of motivations and outcomes, for instance, in the Western world personal motivations (self-expression, recreation, self-improvement, and use of leisure time); musical motivations (love of music, performing for oneself and others, learning more about music); social motivations (meeting new people, being with friends, and having a sense of belonging) (Coffman, 2002); and spirituality (Hinkle, 1988). The benefits to adults of engagement in music making are many and varied. Choral singing seems to have positive emotional, social, physical, and creative outcomes (Beck et al., 2000; Bailey and Davidson, 2002, 2003; Irish,1993) which may also be spiritual (Clift and Hancox, 2001). Membership of amateur operatic societies provides challenge, achievement, and opportunity to escape temporarily the frustrations of everyday living (Pitts, 2004), and music ensembles can provide senior citizens with a venue to make friends, while intergenerational music activities between children, teenagers, and senior citizens have particular social value (Bowers, 1998; Darrow et al., 1994; Leitner, 1982). Music, through community education programmes, can also help adults move toward socio-political transformation (Kaltoft, 1990). Overall, music making contributes to 
perceived good health, quality of life, and mental well-being (Coffman and Adamek, 1999; Vanderark et al, 1983; Wise et al., 1992; Kahn, 1998).

Despite the wide range of research undertaken to date, no research has explored the specific outcomes of engagement in participative music making for those young people who intend to pursue a career in music, although there has been considerable research on the nature of the rehearsal strategies adopted in ensembles (Davidson and King, 2004; Berg, 2000) and the ways in which planning and preparation for performance are undertaken (Goodman, 2000). Social relationships within groups have been explored (Davidson and Good, 2002) trust and respect emerging as crucial for the functioning of small groups working together continuously over long periods of time, e.g. string quartets (Young and Colman, 1979). For long-term success rehearsals have to be underpinned by strong social frameworks as interactions are typically characterised by conflict and compromise (Young and Colman, 1979; Murningham and Conlon, 1991) related mainly to musical content and its coordination, although some interactions are of a more personal nature (e.g. approval). The smaller the group the more important personal friendship seems to be (Blank and Davidson, 2003).

The aim of this paper is to consider the perceived impact of engagement in participative music making, in small or large groups, past or present, on students currently studying music at university. The study is exploratory in nature, hence no specific hypotheses are to be tested. The findings may have implications for all phases of education.

\section{Methodology}


Seventy-eight undergraduate and postgraduate music students from two English universities were asked to report on the impact that their participation in group music making had on their lives. Both music departments emphasized the traditional areas of musical study - the history, theory and aesthetics of Western music from the middle ages to the present day, but newer disciplines such as ethnomusicology, psychology of music, popular music and electro-acoustic studies also formed part of the curriculum. Performance studies including ensemble work were encouraged in both departments and there were strong links with the local community contributing to a thriving cultural life in both.

Students were presented with two questions: How do you perceive your past or current involvement in musical ensembles? What impact did it have on you? The broad nature of the questions was intended to avoid respondents being influenced in their responses by any prompts inferred by the content of the questions. They were allowed, therefore, maximum flexibility to cover any areas of their experience that they chose to and to comment on those aspects that they felt had been affected by their participation in ensemble music making.

The data collected were then analysed using Atlas.ti, a software package for the analysis of qualitative data. The questionnaires were subject to in-depth qualitative analysis based on Interpretative Phenomenological Analysis in line with Smith (1995). The first step was the coding process which involved the close examination of data in order to give names and categorise the emergent phenomena in the data. In other words, similar events and happenings were grouped under a common heading or classification. The concepts that seemed to apply to the same phenomenon were then grouped together. This categorising 
process led to the emergence of categories which were given a more abstract conceptual name than the concepts grouped within each category. In addition, connections among the major categories emerged. Interestingly, in all participants' comments instances of each major category were identified, but the emphasis varied depending on which elements were perceived to have been more important in each particular case. To ensure validity coding was checked by a second coder who independently coded a random sample of responses. There was complete agreement between the coders. The names of all respondents have been changed to ensure anonymity.

\section{Findings}

Three major themes emerged from the data, group music making as a musical act, group music making as a social act, and the perceived effects on the self and personal skills development. Each of these themes had a number of sub-categories.

\section{Group music making as a musical act}

Group music making was firstly perceived as a musical act, which allowed participants to deepen their musical knowledge and gain more insight into the music. Table 1 sets out the main sub-categories to emerge within the theme with example quotes from each and the number and percentage of responses of the total sample. Participants commented on the benefits their ensemble playing participation had on the development of all-round musicianship through gaining access to a wide range of repertoire, building on technical and analytical skills, developing openness and flexibility towards new musical ideas, and becoming increasingly motivated in relation to developing theoretical and practical musical 
understanding. Their listening and sight-reading skills as well as their ability to convey emotions through music were also enhanced. They reported that ensemble playing helped them gain confidence in performing and developed both their solo and ensemble playing skills. Listening to other people led one participant to develop a better inner listening ability. Finally, participating in ensembles was crucial in enhancing intrinsic motivation for music, which in some cases contributed towards the individual pursuing a career in music. For instance, one participant perceived his long-term involvement in a junior band as being 'instrumental' in determining his life aspirations, describing how he progressed through music at General Certificate of Secondary Education level (GCSE) to studying for a degree in music through a progressive enhancement of his intrinsic motivation and love for music.

\section{Table 1 about here}

Below is an example taken from an interview which described the experiences of an accompanist who felt a powerful sense of musical connection to the singer because of the latter's high levels of musical ability. The pianist experienced a powerful emotional reaction to music through ensemble playing participation, which influenced her own playing and motivation.

'Gemma was telling me that it is a magical feeling for her being part of a musical ensemble where all musicians are of a high standard and are talented! There was one time when she was rehearsing an aria in Russian from Tchaikovsky's Dama Pica with a singer. When the singer hit a high A, tears were brought to her eyes! This experience affected her enormously because this emotional reaction of hers was generated purely by the music. This feeling was so powerful that she felt blessed to have had the opportunity to accompany such a magnificent voice! And, interestingly enough, she felt embarrassed to take any 
money from her; she felt that she should have given money to the singer! Another time she was rehearsing in a concert hall with the same soprano who sang like a nightingale! This was the best moment of her accompanying career! As she was rehearsing with the soprano she felt ecstatic again. And when she was asked by the soprano 'what do I owe you?', Gemma wanted to vanish into thin air!! She was ten years old when she had her first ensemble playing experience with violins. 'It was driving me crazy. I couldn't wait for the end of year exams. I was working more on my accompanying parts than on my solo pieces'.

\section{Group music making as a social act}

The music students interviewed regarded their ensemble playing as being of a social nature in addition to their musical involvement. Table 2 sets out the two key emerging themes, their subcategories, and the number and percentage of responses of the total sample in each category. Participants perceived themselves as playing a useful and important role in the group with their contributions being recognised as of equal value to those of others. They also expressed feelings of pride and achievement in relation to their role in the group's success. This seemed to be especially the case in small musical ensembles, such as trios, quartets or small singing groups, as the player could take a leading and primary role because of the degree of musical involvement that was required. This was less marked in larger groups, for instance, orchestras or large bands, although they provided excitement through 'being part of a big sound'. Feelings of being important and useful to the group were also associated with a strong sense of belonging. This resulted from the musician's active contribution to the group outcome, which often gave rise to feelings of satisfaction of achievement. Self-satisfaction was mainly derived from working together in developing 
something that sounded 'good' and 'getting ideas and in turn feeding off other people's creativity and ideas'. Participating in ensembles was also perceived as an opportunity to socialise with like-minded people, make new friends and meet interesting people, who without the musical engagement they would not have had the opportunity to meet. This was particularly important for musicians who would normally play alone, e.g. pianists.

Participants appreciated the opportunities afforded to develop social and teamwork skills through music. Particularly valued were learning to compromise, offering mutual support and encouragement, and learning to work effectively together as a team. Learning to cooperate and exchange ideas for the achievement of a common goal were regarded highly by the participants and raised self-esteem and motivation to work harder to maintain and enhance group standards. An important part of this collaborative musical activity was the fact that participants were able to compare their own performance against that of their fellow musicians, which enabled them either to gain self-confidence or become motivated to put more effort into the task in order to reach the group standards. All in all, the social aspect of group music making seemed to have the potential for the study's participants to create a strong sense of social unity within a group and gave rise to uplifting, exhilarating and motivating feelings. Participants also commented on 'enhanced moods whilst performing', 'exhilaration while in 'flow' - almost like a drug at its best', 'getting lost in a sense of timelessness in the musical act' and performances providing a means of 'escapism'. Participants also appreciated the opportunities afforded to participate in significant musical events, perform in important venues and travel abroad in addition to developing valuable teamwork and social skills:

'We are also having to make up other ensembles for specific events. For example, I am one of 7 students, all from my year (20 of us in total) who are going on an 8 day, 8 gig tour 
in April. We have to work on material for 2.5 hour concerts, with a mixture of solo, duo, trio, whole ensemble performances. I think this will also be very good for us, learning to work effectively with other musicians for one off projects'.

'I love performing on big stages and entertaining the crowd, I've had the opportunity to play in different countries, Northern Ireland, Republic of Ireland, Scotland, England, Holland, France, Germany, Belgium and Norway, various big halls, on TV and radio'.

'I was invited to perform as part of a string quartet with other members of the orchestra and we do performances for a variety of events, e.g. we are soon performing for a new opening at the museum in River County'.

Table 2 about here

\section{Perceived effects on the self - Personal skill development}

In addition to the social benefits there was a range of perceived personal benefits. Table 3 provides example quotes from each emerging category. Participating in an ensemble enhanced feelings of self-achievement for the study's participants, assisted individuals in overcoming challenges, built self-confidence and raised determination to make more effort to meet group expectations regarding standards of playing. As a result, group success and contributions to it enhanced self-esteem, self-efficacy, 'determination to push forward', and the assurances derived regarding ability and achievements, which could not have been attained alone. This resulted in considerable personal satisfaction and enhanced confidence. The skills and confidence developed transferred to performance as an individual. 
In some cases group participation provided an opportunity to develop leadership skills. In addition, playing with others provided role models and standards to aim for and increased motivation, concentration and stamina. Ensemble playing participation was also perceived as an integral part of music students' personal identity as it helped them build up their personality and develop a strong sense of their own identity. One participant's past involvement in school musical events remained vividly in her memory leaving strong traces of happy, active school days when she felt popular and special among other school children.

Given the musical, social and personal benefits that music students reported gaining from their participation in group musical activities, a few expressed disappointment regarding their perception of group music making as 'dying out' in both schools and university music departments:

'I am acutely conscious of the fact that true chamber music is dying out. A focus on Grade examinations and orchestral/band performances contributes to this. This has become a vicious circle. Teachers give pupils no experience of real chamber music; these pupils, if they become teachers, are then in no position to remedy the deficiency'.

'Sadly, performance seems to be undervalued at my University. Even in the 'Techniques of Performance' Module, only $40 \%$ is taken up by actual recital (The other $60 \%$ being Aural exercises). Indeed, one gets the impression that the music department actually looks down its nose at the (mainly student run) student ensembles'.

\section{Table 3 about here}




\section{Relationships between the elements}

Figure 1 sets out the relationships between the musical, social and personal benefits gained from ensemble music making as perceived from the study's participants (see figure 1). As before, the numbers next to each code represent the number of times each code has occurred in the participants' responses. Examination of the figure reveals an important characteristic of group music making for those taking part in terms of their active role in contributing towards the end result. Working as part of the group, participants appreciate the importance of working hard to help maintain the group standards and keep up to group expectations regarding individual contributions. This not only enhances social aspects, such as developing a strong sense of belonging and a feeling of importance and usefulness as a group member, but it also helps to build up confidence and self-satisfaction on a personal level.

\section{Figure 1 about here}




\section{Discussion}

The research reported here indicates the value of playing in small and large groups as perceived by those participating in them. A range of musical skills were developed and consolidated. This aspect of group work was stressed by $41 \%$ of respondents. Playing in groups provides an alternative to individual practice. It increases the amount of time spent playing which facilitates the automation of a wide range of skills technical and musical. It provides extensive opportunities to improve listening and aural skills in real life situations. For those participating in the research, the musical experiences were intrinsically satisfying and acted as a motivational force. The greatest number of responses were in relation to the development of social skills $(55 \%)$. There were considerable perceived social benefits. Participants reported making friends through the groups, learning to co-operate and work as part of a team. Being part of the group made participants feel important and useful, particularly where the groups were relatively small. There was also a sense of communal achievement, and mutual encouragement to do well and achieve high standards. A few participants reported the enhancement of leadership skills. At the personal level the group work presented a challenge, led to considerable individual achievement and improved selfconfidence. For many being part of a group defined their musical identity. $32 \%$ indicated that participation in the group had enhanced their self-confidence. There would seem to be clear benefits in being a member of a musical group. This is not to say that similar benefits could not be derived from belonging to any group. However, the characteristics of musical groups may be particularly important, for instance, the need to co-operate in order to be able to produce a performance in real time, the inter-reliance which is a part of such a performance, and the end product of group work which is usually live performance. 
There are clear implications for music education. Working in large groups, for instance, orchestras and bands clearly provided inspiration and motivated students to continue playing. Working in small groups, provided valuable opportunities for learning from others without the presence of a teacher, developing co-operative skills and ideas. Group work of any nature, large or small, directed or mutually developed was clearly of great benefit to the students at all stages of the development of expertise suggesting that music educators in all educational phases should encourage their students to participate in a wide range of group music making. The higher education music students participating in the research had found group participation of all kinds valuable throughout their musical career, and in general indicated that they had sufficient opportunities within their course to participate in a wide variety of participatory musical activities. There is also an onus on those providing music education in schools, and at area, county or national level to ensure that there are sufficient opportunities for young people to engage in high quality group music making in its various guises. In the music classroom, the UK National Curriculum specifies that children should be provided with opportunities for music making at the individual, group and whole class levels. However, at primary level, many teachers lack the confidence to engage in active music making and the quality of the teaching and the opportunities available for many children limit their experiences, particularly in relation to small group work. This is unfortunate as there are clear benefits to be gained, not only musically, but personally and socially.

\section{References}


Bailey, B.A. \& Davidson, J.W. (2002) 'Adaptive characteristics of group singing: Perceptions from members of a choir for homeless men'. Musicae Scientiae, 6(2), 221256.

Bailey, B.A. \& Davidson, J.W. (2003) 'Amateur group singing as a therapeutic instrument'. Nordic Journal of Music therapy, 12(1), 18-32.

Bailey, B.A. \& Davidson, J.W. (in press) 'Effects of group singing and performance for marginalized and middle class singers'. Psychology of Music

Berg, M.H. (2000) 'Thinking for yourself: The social construction of chamber music experience'. In R.R. Rideout \& S.J. Paul (eds) On the Sociology of Music: Vol 2. Papers from the Music Education Symposium at the University of Oklahoma (pp. 91-112). (Amherst, University of Massachusetts Press).

Blank, M. \& Davidson, J.W. (submitted) A consideration of the effect of gender on coperformer communication in piano duos.

Bowers, J. (1998) 'Effects of an intergenerational choir for community-based seniors and college students on age-related attitudes'. Journal of Music Therapy, 35, 2-18.

Clift, S. \& Hancox, G. (2001) 'The perceived benefits of singing: Findings from preliminary surveys of a university college choral society'. The Journal of the Royal Society for the Promotion of Health, 121(4), 248-256. 
Coffman, D.D. (2002) ‘Adult education'. In R. Colwell \& C. Richardson (eds) The New Handbook of Research on Music Teaching and Learning. (Oxford, Oxford University Press).

Coffman, D.D. \& Adamek, M. (1999) 'The contribution of wind band participation to quality of life of senior adult band members'. Dialogue in Instrumental Music Education, 20(1), 25-34.

Costa-Giomi, E. (1999) 'The effects of three years of piano instruction on children's cognitive development'. Journal of Research in Music Education, 47(5), 198-212.

Costa-Giomi, E., Glimour, R., Siddell, J., \& Levebre, E. (2001) ‘Absolute pitch, early music training, and spatial abilities'. In R. Zattorre and I. Peretz (Eds), The Biological Foundations of Music, Annals of the New York Academy of Science 930, 3294-6.

Darrow, A.A., Johnson, C.M. \& Ollenberger, T. (1994) 'The effect of participation in an intergenerational choir on teens' and older persons' cross age attitudes'. Journal of Music Therapy, 31, 119-134.

Davidson, J.W. \& Good, J.M.M. (2002) 'Social and musical co-ordination between members of a string quartet: an exploratory study'. Psychology of Music, 30, 186-201.

Davidson, J. \& King, E.C. (2004) 'Strategies for ensemble practice'. In A. Williamon (ed.) Musical Excellence. (pp 105-122) (Oxford, Oxford University Press). 
Douglas, S. and Willatts, P. (1994) 'The relationship between musical ability and literacy skill'. Journal of Research in Reading, 17, 99-107.

Gardiner, M.E., Fox, A., Knowles, F. \& Jeffrey, D. (1996) 'Learning improved by arts training'. Nature, 381 (6580), 284.

Goodman, E. (2000) 'Analysing the ensemble in Music Rehearsal and Performance: The Nature and Effects of Interaction in Cello-Piano Duos'. Unpublished Doctoral Dissertation, University of London.

Hallam, S., \& Prince, V. (2000). Research into instrumental music services. (London, DfEE).

Hanshumaker, J. (1980) 'The effects of arts education on intellectual and social development: A review of selected research'. Bulletin of the Council for Research in Music Education, 61, 10-27.

Harland, J., Kinder, K., Lord, P., Stott, A., Schagen, I., \& Haynes, J. (2000). Arts education in secondary schools: Effects and effectiveness. (London, NFER/The Arts Council of England, RSA).

Hetland, L. (2000) 'Listening to music enhances spatial-temporal reasoning: Evidence for the Mozart effect'. The Journal of Aesthetic Education, 34(3-4), 105-148. 
Hinkle, L.B. (1988) 'The meaning of choral experience to the adult membership of the German singing societies comprosing the United Singers Federation of Pennsylvania'. Unpublished Doctoral dissertation, Pennsylvania State University, 1987. Dissertation Abstracts International, 48, 2568A.

Hurwitz, I., Wolff, P.H., Bortnick, B.D. \& Kokas, K. (1975) 'Non-musical effects of the Kodaly music curriculum in primary grade children'. Journal of Learning Disabilities, 8, $45-52$.

Irish, B.M. (1993) Meaning in Music: Cognitive and Affective Response in Adults.

Doctoral Dissertation, Cornell University, 1993. Dissertation Abstracts International, 54, 1198A

Kahn, A.P. (1998) 'Healthy aging: A study of self-perceptions of well-being'. Dissertation abstracts International, 58, 4740B. (UMI No. AAT98-10054)

Kaltoft, G. (1990) 'Music and emancipatory learning in three community education programs'. Dissertation Abstracts International, 51(7), 2239A. (UMI No. AAT90-33861)

Leitner, M.J. (1982) 'The effects of intergenerational music activities on senior day care participant and elementary school children'. Dissertation Abstracts International, 42(8), 3752A. (UMI No. AAT82-02620) 
National Advisory Committee on Creative and Cultural Education (NACCCE) (1999). All our futures: Creativity culture and education. (London, Department for Culture, Media and Sport/Department for Education and Employment).

Ings, R., Jones, R. \& Randell, N. (2000). Mapping hidden talent. (London, The Prince's Trust / National Youth Agency / Youth Work Press).

Murningham, J.K. \& Conlan, D.E. (1991) 'The dynamics of intense work groups: A study of British string quartets'. Administrative Science Quarterly, 36, 165-186.

Pitts, S.E. (2004) 'Everybody wants to be Pavarotti: the experience of music for performers and audience at a Gilbert and Sullivan Festival'. Journal of the Royal Musical Association, $129,149-167$.

Schellenberg, E.G. (2004) 'Music lessons enhance IQ'. Psychological Science, 15(8), 51114.

Smith, J. A. (1995). Semi-Structured Interviewing and Qualitative Analysis. In J. A. Smith, R. Harré \& L. V. Langenhove (Eds.), Rethinking Methods in Psychology. (London, Sage).

Spychiger, M., Patry, J. Lauper, G., Zimmerman, E., \& Weber, E. (1993). ‘Does more music teaching lead to a better social climate'. In R. Olechowski \& G. Svik (eds) Experimental research in teaching and learning. (Bern, Peter Lang). 
Vanderark, S.D., Newman, I., \& Bell, S. (1983) 'The effects of music participation on quality of life in the elderly'. Music Therapy, 3, 71-81.

Wise, G.W., Hartmann, D.J., Fisher, B.J. (1992) 'Exploration of the relationship between choral singing and successful aging'. Psychological Reports, 70, 1175-1183.

Young, V.M. \& Coleman, A.M. (1979) 'Some psychological processes in string quartets'. Psychology of Music, 7, 12-16.

Zulauf, M. (1993) 'Three year experiment in extended music teaching in Switzerland: The different effects observed in a group of French speaking pupils'. Bulletin of the Council for Research in Music Education, 119, Winter, 111-21. 
Table 1: Musical effects of group music making

\begin{tabular}{|c|c|}
\hline $\begin{array}{l}\text { Sub-categories } \\
\text { and number and } \\
\text { percentage of } \\
\text { responses }\end{array}$ & Example quotations \\
\hline $\begin{array}{l}\text { Musical skill } \\
\text { development }-32 \\
\{\mathbf{4 1 \%}\}\end{array}$ & $\begin{array}{l}\text { Ifeel that my past and present involvement in musical ensembles is } \\
\text { an invaluable part of learning about music. I feel that the } \\
\text { participation in an ensemble enables the musician to access a wide } \\
\text { range of musics and to gain a greater in depth knowledge of a } \\
\text { musical ensemble and how music works within the wider } \\
\text { community. }\end{array}$ \\
\hline $\begin{array}{l}\text { Sight reading }-6 \\
\{8 \%\}\end{array}$ & $\begin{array}{l}\text { I think that being in a choir develops your inner ear and enables you } \\
\text { to sing better from sight, and to be able to sing certain awkward } \\
\text { intervals more easily. }\end{array}$ \\
\hline $\begin{array}{l}\text { Gaining } \\
\text { confidence in } \\
\text { performance }-6 \\
\{8 \%\}\end{array}$ & I gained confidence in performing both in a group and as a soloist. \\
\hline $\begin{array}{l}\text { Technical skills } \\
\text { development }-7 \\
\{9 \%\}\end{array}$ & $\begin{array}{l}\text { Another formative experience reinforcing what I subsequently learnt } \\
\text { from my teaching career was my days as a clarinettist in my own } \\
\text { school's Corps Band... } 2 \text { hour rehearsals took place once a week } \\
\text { (they were voluntary). I did no practice but slowly worked my way } \\
\text { up from being 4th to Solo Clarinet. This was where I developed most } \\
\text { of my technical, sight reading and ensemble skills. }\end{array}$ \\
\hline $\begin{array}{l}\text { Learning to listen } \\
-12\{15 \%\}\end{array}$ & $\begin{array}{l}\text { Having to listen to other people has made me more aware of the } \\
\text { need to listen to my own playing when I am in a solo setting. } \\
\text { Ensemble has also made a huge difference to how I listen to music. I } \\
\text { am now much more analytical, critical, etc. I am aware of what is } \\
\text { going on within a piece of music or arrangement. } \\
\text { We attempted Benjamin Britten's War Requiem, which was, both } \\
\text { rhythmically and melodically difficult. On that occasion, I found the } \\
\text { conductor almost impossible to follow, as the beat was never really } \\
\text { clear. I could not understand what the conductor was doing with his } \\
\text { arms even during passages when the music seemed uncomplicated. I } \\
\text { found that I had to count like mad and became used to listening to } \\
\text { other parts to help me get the entries right. }\end{array}$ \\
\hline $\begin{array}{l}\text { Improved playing } \\
\text { ability }-10\{12 \%\}\end{array}$ & $\begin{array}{l}\text { I am currently a 1st violinist in a youth orchestra. I joined because I } \\
\text { felt unhappy with my recital last year and wanted to enhance my } \\
\text { playing skills for this year's recital. } \\
\text { Having not played in an ensemble for a few years has damaged my } \\
\text { rhythmic work and tightness of performance. }\end{array}$ \\
\hline
\end{tabular}




\begin{tabular}{|c|c|}
\hline $\begin{array}{l}\text { Deepening } \\
\text { Musical } \\
\text { knowledge }-9 \\
\{12 \%\}\end{array}$ & $\begin{array}{l}\text { Much of my musical knowledge, in all areas, has been derived from } \\
\text { my participation in performance groups, and I hold it crucial to the } \\
\text { continuation of my development. }\end{array}$ \\
\hline $\begin{array}{l}\text { Opening up to } \\
\text { different } \\
\text { perspectives }-4 \\
\{5 \%\}\end{array}$ & $\begin{array}{l}\text { Participating in an ensemble allows me as a musician to build upon } \\
\text { my technical skills as a soloist and as a musician within a wider } \\
\text { overall structure within an ensemble, it also opens up my views to } \\
\text { the different perspectives of other musicians and their approach to } \\
\text { the study and practice of music. }\end{array}$ \\
\hline $\begin{array}{l}\text { Emotional } \\
\text { expression }-5 \\
\{6 \%\}\end{array}$ & $\begin{array}{l}\text { I have joined ensembles for both enjoyment purposes and to further } \\
\text { my abilities as a performer. I believe that being able to interact } \\
\text { with other performers has helped me to improve musically in a } \\
\text { technical sense, and to be able to convey emotions through music } \\
\text { much better. }\end{array}$ \\
\hline $\begin{array}{l}\text { Access to } \\
\text { repertoire }-7 \\
\{9 \%\}\end{array}$ & $\begin{array}{l}\text { It was also a lovely way to get to know the music much more } \\
\text { intimately than just listening to it. }\end{array}$ \\
\hline $\begin{array}{l}\text { Intrinsic } \\
\text { motivation }-8 \\
\{10 \%\}\end{array}$ & $\begin{array}{l}\text { The impact of working within an ensemble motivates you as a player } \\
\text { to learn more about the theoretical issues of music and to build } \\
\text { upon your practical musicianship skills in order to be more effective } \\
\text { within the environment of the ensemble in which you participate. }\end{array}$ \\
\hline $\begin{array}{l}\text { Junior Band } \\
\text { conducive to } \\
\text { further interest and } \\
\text { involvement }-4 \\
\{5 \%\}\end{array}$ & $\begin{array}{l}\text { I played for a Junior Band from the ages of } 7 \text { to } 19 \text { and this } \\
\text { experience has been instrumental on my life. It was through this } \\
\text { brass band, and specifically the conductor, that I was introduced to } \\
\text { music. Originally I attended the band mostly because my parents } \\
\text { wanted me to, and later for social aspects. However, the } \\
\text { involvement in the band led me to take GCSE music which } \\
\text { broadened my horizons somewhat. I began to value the band for } \\
\text { musical as well as social aspects and my success at GCSE music led } \\
\text { to A-level music which in turn progressed into a BA (hons) in Music. }\end{array}$ \\
\hline
\end{tabular}


Table 2: Social effects

\begin{tabular}{|c|c|}
\hline $\begin{array}{l}\text { Sub-categories } \\
\text { and number and } \\
\text { percentage of } \\
\text { responses }\end{array}$ & Example quotations \\
\hline $\begin{array}{l}\text { Social } \\
\text { involvement }-21 \\
\{27 \%\}\end{array}$ & Not only musically, you're socially involved also. \\
\hline $\begin{array}{l}\text { Active } \\
\text { contribution to the } \\
\text { group outcome - } \\
14\{18 \%\}\end{array}$ & $\begin{array}{l}\text { With the support of an excellent teacher/international performer } \\
\text { and a very supportive group of peers, I began to enjoy it more and } \\
\text { felt that I could contribute ideas to the group. }\end{array}$ \\
\hline Equality $-6\{8 \%\}$ & $\begin{array}{l}\text { I perceive musical ensembles as working, in some ways, like } \\
\text { clockwork: one has to believe that each part/person is of equal } \\
\text { importance. }\end{array}$ \\
\hline $\begin{array}{l}\text { Small group }-8 \\
\{10 \%\}\end{array}$ & $\begin{array}{l}\text { Small singing group, one person per part is great as I feel like I } \\
\text { am making a valuable contribution. } \\
\text { The jazz and rock bands gave me a feeling of importance on drum } \\
\text { kit because in a trio, I am not just background noises such as the } \\
\text { case when playing goofy Christmas songs, i.e. the whip sound for } \\
\text { a horse and sleigh or jingle bells - extremely boring and a } \\
\text { constant self-questioning of why the hell did I sign up for this. }\end{array}$ \\
\hline $\begin{array}{l}\text { Feeling } \\
\text { important/useful - } \\
10\{13 \%\}\end{array}$ & $\begin{array}{l}\text { You feel important as you are part of a group of people with an } \\
\text { equally important part to play as anyone else. }\end{array}$ \\
\hline $\begin{array}{l}\text { Sense of belonging } \\
-11\{14 \%\}\end{array}$ & $\begin{array}{l}\text { Ifeel that ensemble has been a major factor in making me feel that } \\
\text { I belong on the course and have a valid place. } \\
\text { Belonging to the groups was a great social experience and made } \\
\text { me feel special (because I got to be a soloist). }\end{array}$ \\
\hline $\begin{array}{l}\text { Group success - } \\
17\{22 \%\}\end{array}$ & $\begin{array}{l}\text { Importance as feeling part of the group and in part contributing } \\
\text { towards the sound and sensation. Being satisfied when we all just } \\
\text { know that something we've worked on together sounds good (like a } \\
\text { 'click'). }\end{array}$ \\
\hline $\begin{array}{l}\text { Satisfaction of } \\
\text { achievement }-19 \\
\{24 \%\}\end{array}$ & $\begin{array}{l}\text { Not only musically, you're socially involved also. When } \\
\text { everything fits together, you feel a sense of achievement as you } \\
\text { were part of a group that 'made' music happen. }\end{array}$ \\
\hline $\begin{array}{l}\text { Working with like } \\
\text { minded people }-9 \\
\{12 \%\}\end{array}$ & $\begin{array}{l}\text { Facilitates social interaction with like-minded people. } \\
\text { Good opportunity to be part of a group of like-minded music } \\
\text { makers, as being a pianist can be quite lonely as rehearsals are } \\
\text { mainly solo. }\end{array}$ \\
\hline $\begin{array}{l}\text { Making friends - } \\
18\{23 \%\}\end{array}$ & Opportunity to make lasting friendships around a common aim. \\
\hline
\end{tabular}




\begin{tabular}{|c|c|}
\hline & $\begin{array}{l}\text { Through musical activities I have made the majority of my close } \\
\text { friends because we all share the same passion for music and enjoy } \\
\text { making it together. }\end{array}$ \\
\hline $\begin{array}{l}\text { Meeting } \\
\text { interesting people } \\
-6\{8 \%\}\end{array}$ & $\begin{array}{l}\text { It enabled me to meet a large diverse group of people who I } \\
\text { probably wouldn't have had the opportunity to meet. } \\
\text { The music groups are full of unusual, interesting and intelligent } \\
\text { people. }\end{array}$ \\
\hline $\begin{array}{l}\text { Novel/unique } \\
\text { performing } \\
\text { experiences }-6 \\
\{8 \%\}\end{array}$ & $\begin{array}{l}\text { Through music, and again specifically the conductor and the } \\
\text { Junior Band, I have toured Europe, made some very close friends } \\
\text { and opened up my life to many new experiences. }\end{array}$ \\
\hline $\begin{array}{l}\text { Social skill } \\
\text { development }-43 \\
\{55 \%\}\end{array}$ & $\begin{array}{l}\text { It is not only an exercise in musicianship but also people / peer } \\
\text { management. } \\
\text { Improvements in general people skills. }\end{array}$ \\
\hline $\begin{array}{l}\text { Teamwork skills - } \\
20\{26 \%\}\end{array}$ & $\begin{array}{l}\text { I learnt many things including how to work in a team. } \\
\text { As a member of such a group, you get really engaged into } \\
\text { teamwork, so there is another wonderful perspective added to your } \\
\text { artistic involvement. }\end{array}$ \\
\hline $\begin{array}{l}\text { Co-operation }-11 \\
(14 \%\}\end{array}$ & $\begin{array}{l}\text { We mostly function collectively trying to spread the influence of } \\
\text { each person, on the music, as evenly as possible. It feels nice } \\
\text { doing things this way. } \\
\text { No one was really responsible for the orchestration of the pieces. } \\
\text { Each one of us decided in a completely democratic manner, } \\
\text { bearing in mind the prevailing opinion of the group. We all felt } \\
\text { that we had helped each other considerably not only as far as the } \\
\text { musical aspect was concerned but also in relation to our co- } \\
\text { operation }\end{array}$ \\
\hline $\begin{array}{l}\text { Learning to } \\
\text { compromise }-7 \\
\{9 \%\}\end{array}$ & $\begin{array}{l}\text { It has improved my social skills and my ability to work with people } \\
\text { who are not all at the same standard and to learn that compromise } \\
\text { is necessary in any group, regardless of the standard. }\end{array}$ \\
\hline $\begin{array}{l}\text { Being encouraging } \\
-8\{10 \%\}\end{array}$ & $\begin{array}{l}\text { It takes music making to a new level. When you play on your own, } \\
\text { it is like recreating notes in your own style and expression, but in } \\
\text { a group you have to work together to make it into music. It is } \\
\text { easier to get motivated. When you aren't inspired to play, there is } \\
\text { always somebody else to encourage you to keep going. }\end{array}$ \\
\hline $\begin{array}{l}\text { Sharing ideas for a } \\
\text { common goal }-7 \\
\{9 \%\}\end{array}$ & $\begin{array}{l}\text { We share ideas on composition issues. We are very lucky to have } \\
\text { the same feeling for music and sharing the same expectations. }\end{array}$ \\
\hline $\begin{array}{l}\text { Self-comparison to } \\
\text { others }-11\{14 \%\}\end{array}$ & $\begin{array}{l}\text { Makes me think more about the way I play/perform. Sometimes I } \\
\text { notice that I have different techniques to others. Might feel like } \\
\text { I'm not as good technically as some but better than others. } \\
\text { When I finally joined the County Youth Concert Band, it was an } \\
\text { amazing step up that opened my eyes to how many other good }\end{array}$ \\
\hline
\end{tabular}




\begin{tabular}{|l|l|}
\hline & musicians there were around and how far I still had to go. \\
\hline $7\{9 \%\}$ & $\begin{array}{l}\text { Our first performance was not part of the assessment, it was } \\
\text { mostly an occasion for the musicians to develop bonding and } \\
\text { cohesion as an ensemble. } \\
\text { Orchestras are beneficial in developing not only technical skills } \\
\text { but also your sense of playing in a group - watching the conductor } \\
\text { and playing together and creating a blended sound, and feeling } \\
\text { the dynamics together as a group. }\end{array}$ \\
\hline $\begin{array}{l}\text { Effort to reach and } \\
\text { maintain group } \\
\text { standards - } 13 \\
\{17 \%\}\end{array}$ & $\begin{array}{l}\text { Being involved in ensemble performance was of the greatest } \\
\text { importance when I was at school - the amount I gained from it was } \\
\text { enormous, along the lines of working with and listening to others, } \\
\text { watching the conductor, patience (because rehearsals never go the } \\
\text { way you want them to!) and a friendly competitive atmosphere in } \\
\text { which I aimed higher than I otherwise might have done. }\end{array}$ \\
\hline $\begin{array}{l}\text { Flow experience - }- \\
6\{8 \%\}\end{array}$ & $\begin{array}{l}\text { Exhilaration while in 'flow' - almost like a drug at its best. } \\
\text { Getting lost in a sense of timelessness in the musical act. }\end{array}$ \\
\hline
\end{tabular}


Table 3: Personal effects

\begin{tabular}{|c|c|}
\hline $\begin{array}{l}\text { Sub-categories } \\
\text { and number and } \\
\text { percentage of } \\
\text { responses }\end{array}$ & Example quotations \\
\hline $\begin{array}{l}\text { Overcoming } \\
\text { challenges }-10 \\
\{13 \%\}\end{array}$ & $\begin{array}{l}\text { This year, I am with a different group of people, different facilitator } \\
\text { and we have a year's experience under our belts. Ifeel much more } \\
\text { able to contribute ideas, some of which have been very significant in } \\
\text { terms of arrangement and performance. The praise I have received } \\
\text { for these, the success of the finished pieces, our satisfaction with } \\
\text { them and the positive feedback from performance, has been very } \\
\text { encouraging. } \\
\text { Feeling of being 'useful' in the group, assurance of my ability; } \\
\text { achievement which may not happen by myself; motivated to } \\
\text { overcome challenges; result in satisfaction and confidence. }\end{array}$ \\
\hline $\begin{array}{l}\text { Self-confidence } \\
\text { building }-25 \\
\{32 \%\}\end{array}$ & $\begin{array}{l}\text { As I have been involved with it for many years, it has helped to } \\
\text { develop my personality - making me more confident to work } \\
\text { individually and with my peers. } \\
\text { I am however, still a very unconfident solo performer, but hope this } \\
\text { will also improve. I feel that I have made huge progress in } \\
\text { ensemble and that this has impacted on other areas also. }\end{array}$ \\
\hline $\begin{array}{l}\text { Self-achievement } \\
-12\{15 \%\}\end{array}$ & $\begin{array}{l}\text { Being in an orchestra and choir gave me a sense of achievement } \\
\text { and confidence. } \\
\text { Having come through the first year with positive feedback, } \\
\text { assessment results, etc. I have started the second year with a more } \\
\text { positive personal attitude and a determination to push myself more } \\
\text { this year. This is working so far. I think the experience of taking } \\
\text { part in the Ensemble module and performing as part of an ensemble } \\
\text { has been significant in other areas of my life, too. I am generally } \\
\text { less apologetic for being me and more confident. I am able to } \\
\text { consider myself as a musician, as well as a singer. }\end{array}$ \\
\hline $\begin{array}{l}\text { Leadership skills } \\
-4\{5 \%\}\end{array}$ & $\begin{array}{l}\text { In particular, I have gained confidence in my leadership skills } \\
\text { through conducting the Concert Band. } \\
\text { This has provided me with the opportunity to develop leadership } \\
\text { skills. }\end{array}$ \\
\hline $\begin{array}{l}\text { Concentration }-8 \\
\{10 \%\}\end{array}$ & $\begin{array}{l}\text { I tend to concentrate hard in full orchestral rehearsal, especially at } \\
\text { difficult passages! } \\
\text { I became better at concentration. } \\
\text { The whole experience was very valuable for the development of } \\
\text { social behaviour, ability of co-operation with other people and } \\
\text { concentration in order to perform on time and synchronise with the }\end{array}$ \\
\hline
\end{tabular}




\begin{tabular}{|c|c|}
\hline & rest of the choir, the orchestra and the conductor.... \\
\hline $\begin{array}{l}\text { Stamina }-3 \\
\{4 \%\}\end{array}$ & Increased motivation, concentration and stamina. \\
\hline $\begin{array}{l}\text { Integral part of } \\
\text { identity }-9 \\
\{12 \%\}\end{array}$ & $\begin{array}{l}\text { I've been involved in musical ensembles for most of my life, so they } \\
\text { now seem to be part and parcel of who I am; if I had no } \\
\text { Choir/Orchestra/String Quartet to play in I'd be lost!. } \\
\text { I cannot imagine what my life would be like were music not } \\
\text { involved, and this can all be traced back to when I was } 7 \text { years old } \\
\text { and starting in the band. } \\
\text { It's helped to make me the person I am today. } \\
\text { Ifeel that being involved in musical ensembles defines me as a } \\
\text { person. I play in a band which has developed its own identity over } \\
\text { the past couple of years, and that identity is a direct reflection of the } \\
\text { attitudes of the four members. Not a day goes by without some effort } \\
\text { being made towards what is happening with the band, and as such it } \\
\text { is a big part of our lives. ... my whole life seems to be leading up to } \\
\text { the next performance. Beyond that, all your mates think you know } \\
\text { everything about music if you play in a band. They are not bothered } \\
\text { if you have a degree in it, they are bothered if you can actually DO } \\
\text { it, and I think in many ways I agree with that idea. }\end{array}$ \\
\hline $\begin{array}{l}\text { Strong memory } \\
\text { traces of school } \\
\text { musical activity - } \\
6\{8 \%\}\end{array}$ & $\begin{array}{l}\text { Apart from the above, what remained very vividly in my mind from } \\
\text { my school experience are all these events (celebrations at national } \\
\text { holidays...) and not a common lesson of language or maths in the } \\
\text { classroom - unique experiences because of their practical nature } \\
\text { and because of the feeling of satisfaction after the completion of } \\
\text { each successful event, and the satisfaction of being an active } \\
\text { member who contributed to the successful outcome of the event. } \\
\text { I was feeling in a favourable position because I was the only one } \\
\text { chosen out of the other young pianists. I was also feeling active and } \\
\text { one of the few, since other kids were not involved in any of these } \\
\text { events-everyone knew me. }\end{array}$ \\
\hline
\end{tabular}




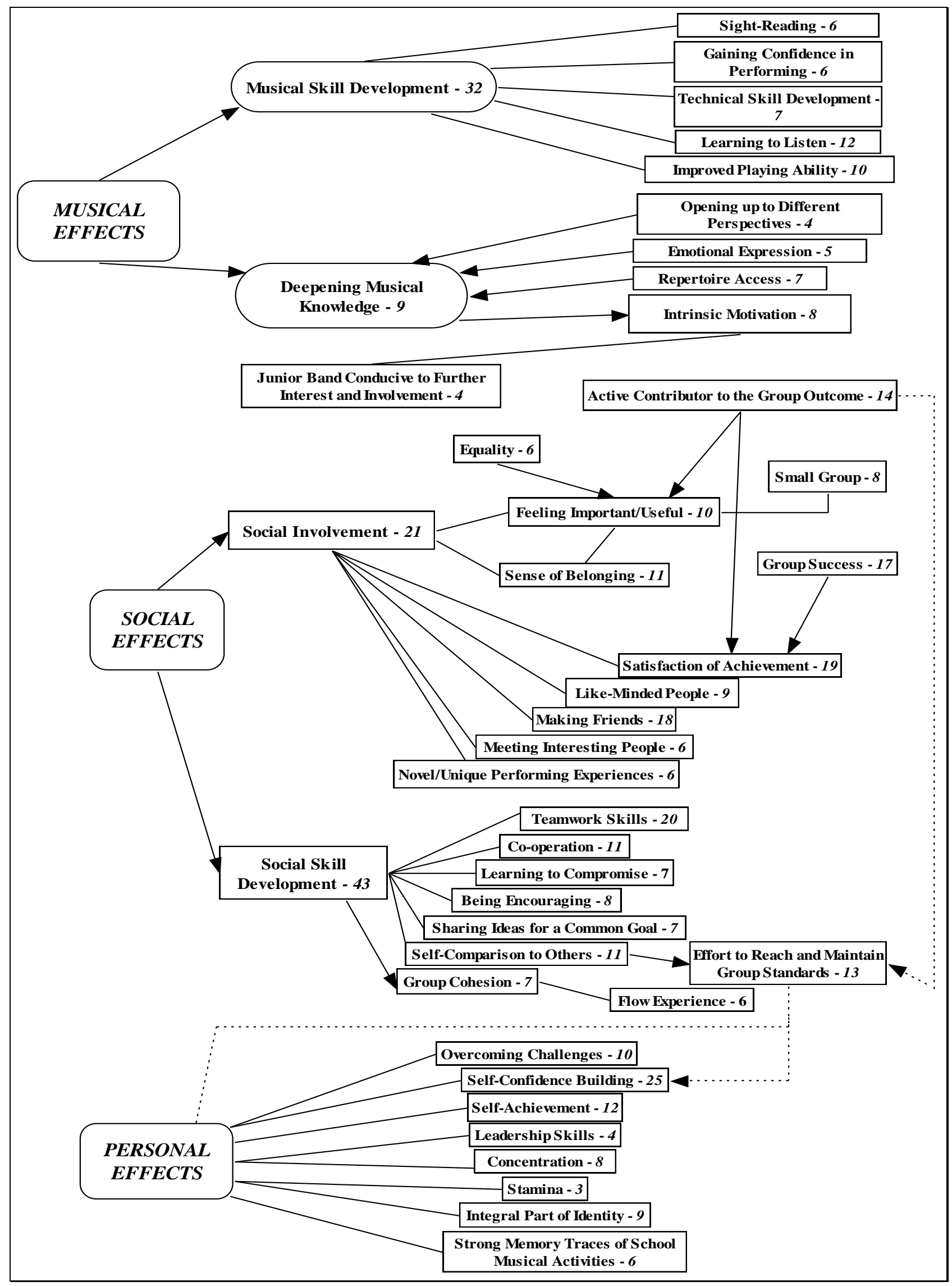

Figure 1: Effects of Ensemble Playing as Perceived by Music Students 
